\title{
Tourist Activity and Destination Brand Perception: The Case of Cape Town, South Africa
}

\author{
${ }^{1}$ Ikechukwu O. Ezeuduji, ${ }^{2}$ Kirsti Lee November, ${ }^{3}$ Chelsea Haupt \\ ${ }^{1}$ University of Zululand, South Africa \\ 2,3Cape Peninsula University of Technology, South Africa \\ ezeudujii@unizulu.ac.za, ezeuduji3@yahoo.com
}

\begin{abstract}
A respondent-completed questionnaire in Cape Town, South Africa was used to check how the activities that tourists enjoyed in Cape Town relate to how they perceive this destination using brand descriptive variables (brand essence, brand image and brand loyalty). 200 questionnaires were received for bivariate and multivariate analyses. This study finds that although tourists found most activities in Cape Town enjoyable; nature and outdoor, food and wine, and shopping enjoyment have more impact in determining the general experience satisfaction of tourists, than beach, and surprisingly, history and cultural activities. Nonetheless, tourists generally perceive Cape Town quite positively. From analyses, this study strongly suggests that the brand position statement for Cape Town should revolve around unique and diverse tourists' attractions in Cape Town, and the memorable experience with which tourists go home from Cape Town. The brand position statement should be linked to Cape Town tourism's integrated marketing communications. This study can assist tourism business owners in Cape Town to evaluate and improve tourism offerings to meet the expectations of visitors, contributing to visitors forming a positive perception towards Cape Town. The findings have implications for similar destinations in the developing economies.
\end{abstract}

Keywords: Tourism activity, tourist experience, destination brand perception, Cape Town, South Africa

\section{Introduction}

Wesgro, the Destination Marketing, Investment and Trade Promotion Agency for the Western Cape (one of South Africa's nine provinces, with Cape Town as the capital city) labelled the brand promise of the Western Cape as 'be inspired and discover new experiences' (The Western Cape destination marketing, investment and trade promotion agency of South Africa, 2013). Cape Town, in 2014 topped the list of New York Times' '52 top places to go in 2014' (New York Times, 2014) and received an 8.2\% increase in visitor arrivals to the city in January 2015 in comparison to the previous year (The Western Cape Destination Marketing, Investment and Trade Promotion Agency- South Africa, 2015). Cape Town is South Africa's second most visited city, after Johannesburg, with an estimated 389012 visitor arrivals at the Cape Town International Airport in July 2015 (Airports Company of South Africa, 2015). The major motivators for travel to Cape Town have been identified as nature, culture and heritage purposes (City of Cape Town, 2013). Cape Town is also emerging as a leading business and events destination in South Africa. The tourism industry has been acclaimed as a major contributor to global economic development and serves as a source of income generation for many developing countries (Wijethunga \& Warnakulasooriya, 2014), including South Africa. The South African tourism industry in 2014 had contributed over 9\% to the country's Gross Domestic product (GDP) through its direct and indirect impacts and also provided over 1.4 million employment opportunities (South African Tourism, 2015).

The tourism industry is quite competitive with its continuously changing trends and increasing tourist expectations (Okumuş \& Yaşin, 2008).The perceptions that potential tourists have of Cape Town can have a huge influence on the viability and long-term survival of Cape Town as a tourist destination (Prayag, 2007). The increasingly popularity of Cape Town as a tourist destination makes it crucial to create a linkage between the marketed image and the perceived image of this destination. Among the tourists, a destination's brand essence needs to match their experience to create a positive perception of that destination (Perović, Stanovčić, Moric, \& Pekovic, 2012). Lopes (2011) also suggested that the perceptions tourists have towards the image of a destination is the most influential factor during the tourists' decision making process towards choosing a destination as a destination with a positively stronger brand image is more likely to be selected. A 
tourism destination is defined as 'an amalgam of individual products and experience opportunities that combine to form a total experience of the area visited' (Murphy, Pritchard, \& Smith, 2000: 44). Gâslason (2013) regarded a tourist destination as a city, region or country that a tourist temporarily travels to in addition to all the tourism products/services and supporting services the tourist makes use of staying at the destination. Hence, it is not only a physical location, but also a combination of tangible elements (accommodation, food and beverage, attractions) and intangible elements (culture, heritage, ambience and tourist experience) that provide an overall visitor experience (George, 2011).

In a tourism destination, tourism demand meets supply. While tourism destinations offer destination experience to tourists, the destination awareness, perception and preferences are suggested by Dwyer and Kim (2003) as demand factors that form parts of the destination competitiveness' determinants. Crouch (2011) also emphasised the importance of a destination's image and its reputation in the tourism market. Tourists' awareness and image of a destination is a product of various information they have obtained about the destination which shape how they perceive the destination. Cessford (2003) studied the perception and realities of tourist experience in a destination and found both to be sometimes opposing. Destinations undertake marketing activities towards branding and positioning of their respective destinations. Research by Crouch (2011) suggested that the awareness and image of a destination amongst tourists are similarly crucial to destination's competitiveness, however many other external information about a destination are beyond the control of a destination, but can affect tourist perceptions. He (Crouch, 2011) then posited that the critical role of destination's attractiveness involves two essential dimensions: the reality of the destination's attributes and qualities (destination's appeal), and how this reality is communicated to and perceived by tourists (destination's knowledge and understanding), in comparison to the other information received about other destinations.

Consumers do not simply pay for services; they do pay for service brands (de Chernatony \& Harris, 2010; Ezeuduji, Lete, Correia \& Taylor, 2014). Kapferer (1997) posited that the value of a brand culminates from consumers' awareness of it, their trust in it and the image and reputation it has for them. Brands do offer consumers various tangible and intangible benefits over unbranded offerings thereby resulting in the value of the companies owning the brands to increase. Successful brands are those that present valuable marketing assets arising from the coherent blending of marketing resources. In the presence of well-conceived and effectively managed brands, organizations may build favourable reputations, increasing the confidence of buyers and users (de Chernatony \& Harris, 2010). deChernatony and McDonald (1998: 20) regarded a successful brand as "an identifiable product, service, person or place, augmented in such a way that the customer or consumer perceives relevant, unique, added values which match their needs most closely". Rahi (2015) inspected the moderating relationship of brand image between internet banking and customer loyalty, and found that there is a significant quasi moderation effect between Internet banking and customer loyalty. This means that if the brand image is strong there will be a positive relationship between internet banking and customer loyalty. Previous researchers such as Dick (1994), Edvardsson, Johnson, Gustafsson, and Strandvik (2000), and Hallowell (1996) pointed to the importance of brand essence and brand image towards achieving brand loyalty, especially for service providers. Tourism is service-orientated, it is therefore expected that destination brand essence and image will play critical roles towards destination loyalty.

Recently, many authors studied tourism destination brand perception (such as Artuğer, Çetinsöz, \& Kiliç, 2013; Beerli \& Martin, 2004; Bertan \& Altintaş, 2013; Gursoy, Chen \& Chi, 2014; Hosany, Ekinci \& Uysal, 2007; Ibrahim \& Gill, 2005; Jraisat, Akroush, Alfaouri, Qatu \& Kurdieh, 2015; Kiliç \& Sop, 2012; Lopes, 2011; Molina, Gómez \& Martín-Consuegra, 2010; Nel \& Strydom, 2004; Prayag, 2010; Puh 2014; Qu, Kim \&Im, 2011; Rajesh, 2013; Tasci \& Gartner, 2007). These aforementioned authors did research the impacts of tourist perceptions, tourists' satisfaction, destination brand, destination personality, destination image, and destination loyalty, mostly outside Africa. Research with a focus on destination brand perception in Africa is limited; hence this study will provide more insight into tourists' perception of a popular South African tourism destination (Cape Town). This study will take the angle of tourists' activity and how these relate to how they perceive different brand descriptive variables (brand essence, brand image and brand loyalty) in a destination (Cape Town). Studies by Nel and Strydom (2004), and Prayag (2010) were done in Bloemfontein and Cape Town respectively in South Africa, focussing on brand image perceptions of international tourists. This research however will compare domestic and international tourists' perceptions in Cape Town. Globally, the tourism 
industry like any other industry is characterised by customers' ever-changing behaviour and demands (Ezeuduji, 2015). Hence, studies on tourism destination brand perception always need to be updated. This study will provide updated information on the tourists' activity and how they compare to destination brand perception in Cape Town, South Africa. Results from this study could be compared with related findings in the international literature. This study can also assist tourism business owners in Cape Town to evaluate and improve tourism offerings to meet the expectations of visitors, contributing to visitors forming a positive perception towards Cape Town.Integrated marketing communications in Cape Town can be positioned as consistent and coherent forces to reinforce behaviour (as in advertising), or as an avenue of achieving mutual understanding between Cape Town and her publics (as in public relations) in order to justify and preserve its asset of reputation (O'Sullivan, 2010). The findings of this study can have significant implications for similar destinations in the developing economies, globally.

\section{Literature Review}

Tourist perception: Dimmock (2012) described perception as a mental process by which the sensory inputs of an individual are processed, organised and interpreted. The perceptions that potential tourists have about a destination represents their degree of knowledge about the destination's attributes (Okumuş \& Yaşin, 2008), offerings and expected quality of experience provided. How tourists perceive a destination is considered to have a major influence on destination choice (Gao \& Zhang, 2009) as potential tourists are able to compare the attributes of different destinations during their decision making process. Destinations that are perceived to provide potential tourists with the closest form of travel expectations are more likely to be chosen over competing destinations (Prayag, 2003). Positively perceived destinations therefore have a higher propensity of tourists deciding to return as well as encouraging others to visit same destination (Wijethunga \& Warnakulasooriya, 2014). Destination choice therefore rests largely on the perceptions that potential tourists have towards a particular destination (Prayag, 2003).Factors influencing tourists' overall perception of a destination include mainly: (a) the information that tourists receive before travelling to a destination (Hosany et al., 2007; Gao \& Zhang, 2009), and (b) the attitude a tourist has towards the attractiveness, quality and value of the experience received while at a destination (Quintal \& Polczynski, 2010).

Lopes (2011) further suggest that physiological factors such as motivation for travel could also influence the choice of destination during the tourists' decision-making process. The socio-demographic variables of a tourist such as age, level of education and beliefs could also influence the way in which information received about a destination is selected and organised, resulting in each tourist interpreting the information received differently, creating their own unique perception of a destination (Gao \& Zhang, 2009). Previous travel could also influence the perception of the destination. The perceptions of first time visitors are usually organic and are based on expectations whereas the perceptions of return visitors can be directly influenced by past experiences to the destination (Gao \& Zhang, 2009). The results of a study conducted by Molina et al. (2010) revealed that the information gathered through destination marketing activities is often the first point of contact that a tourist has with the destination and has a significant influence on the formation of tourist perceptions. Awuah and Reinert (2011) concurred, as results of their study revealed that the perceived image that potential tourist have prior to visiting a destination is largely influenced by information collected from the internet, print advertisement and marketing campaigns of the destination. Although the information received through external sources has a huge influence on the overall perceptions of potential tourists, the previously mentioned study conducted by Molina et al. (2010) revealed that the direct contact that a tourists has with the destination, its local people, employees, facilities and services appeared to be the most influential component in the overall creation of tourist perceptions.

A study conducted by Bertan and Alvintas (2013) on the perception of visitors towards Pamukkale, Turkey, showed that the socio-demographic variables of tourists had a significant influence on the way tourists perceived the destination. Tourists between the ages of 22-30 indicated that Pamukkale had a unique atmosphere in comparison to tourists between the ages of 36-40, who answered that Pamukkale had a less unique atmosphere in comparison to other destinations, while tourists with a higher level of education perceived Pamukkale as having a low service quality in comparison to tourists that had a lower level of formal education who perceived Pamukkale as having high service quality (Bertan \& Alvintas, 2013). Taking the above into consideration, the overall perceptions that a tourist has of a destination is a multidimensional 
construct (Puh, 2014) as it is influenced by a number of external information sources, social characteristics, as well as by the direct destination experience. Due to the competitive nature of the tourism industry, potential tourists can compare the attributes of different destinations during their decision making process. Destinations therefore compete based on the perceived image of potential tourists (Okumuş \& Yaşin, 2008).

Destination brand image: Brand image has been recognised as one of the most important elements of a destination (Lopes, 2011) as it has a strong influence on a tourist's motivation, preferences and behaviour towards tourism product or services that contributes to the pull factor for an individual to visit a destination. Keller (2003) depicted brand image as the sum of brand perceptions reflected by the brand association that are retained in consumer memory. Brand image is focused on the way in which a group of people or an individual perceives a product or service, a brand, an organisation, or a destination. Destination image is one of motivators in the travel and tourism industry. The attitudes and perceptions customers have towards a particular tourism product or destination influences the buying need of an individual (Nel \& Strydom, 2004). The competitive nature of the tourism industry has provided potential tourists with a choice of broad range of destinations and tourist activities to select from. Therefore the attitude and images that tourists have towards a destination can significantly influence an individual buying decisions. Brand image plays a role in creating the satisfaction of the customers and the characteristics of the product or services are influenced by how customers perceive the brand (Lopes, 2011). Brand image is a multidimensional construct as it is influenced by a number of factors from the tourist's perspective, such as cognitive images (destination attributes), affective images (emotional evaluation of destination attributes) (Rajesh, 2013; Lopes, 2011), external information sources (Tasci \& Gartner, 2007), socio-demographic characteristics (Beerli \& Martin, 2004), as well as by the direct experience of the tourist (Lopes, 2011). Formation of the overall image of a destination results from the combination of all these factors.

Destination brand essence: Brand essence captures the core spirit of a brand, the functional and emotional benefits of a brand (de Chernatony \& Harris, 2010). It identifies the brand's competitive advantage and the benefits received when choosing a brand over its competitors (Light, Kiddon, Till, Heckler, Mathews, Hall \& Wacker, 2012). Unlike many commercial products and services, the purchase of tourism offerings is usually infrequent (Wijethunga \& Warnakulasooriya, 2014) and consists of a large amount of planning beforehand. Hence, potential tourists are most likely to select a destination that has the most favourable image (Wijethunga \& Warnakulasooriya, 2014) and can provide the benefits demanded for when taking a trip outside of their usual environment. The benefits (functional and emotional) received when travelling to a destination is communicated through the brand essence of a destination. Functional benefits can be described as the primary purpose for travelling to a destination. Depending on the tourists' motivation to travel, this includes visiting attractions and sight-seeing, attending business events and conferences, for medical care or to visit friends and family. In addition, the functional benefits sought include tangible elements of the tourist experience. This consists of the destinations' physical attributes, which make up a destination. The quality of the physical infrastructure and facilities of a destination such as accommodation and transportation network systems form the foundation upon which tourism services are produced in a destination, while the variety of attraction and activities of a destination serve as pull factors during the decision making of potential tourists (Pawitra \& Tan, 2003; Vengesayi, 2003).The emotional benefits can be described as the intangible benefits received during the visit at a destination. These are the additional benefits that a tourist did not expect to receive when deciding to travel to a destination. These benefits include self-development, health and relaxation as well as the ability of the destination to provide tourists with new experiences (Chen, 2012; Pawitra \& Tan, 2003). As tourism offerings are consumed and experienced outside of a tourists usual environment (Wijethunga \& Warnakulasooriya, 2014), this contributes to the cross-cultural experience between the local people and tourists. The cross-cultural interaction between locals and tourists results in the breaking down of stereotypes and misconceptions from both sides. It also contributes to the knowledge development of tourists, to learn something different from what they are exposed to in their usual environment.

Research conducted by Albayrak, Caber and Aksoy (2010), show that the tangible elements of the tourism product had a greater impact on customer satisfaction compared to the intangible elements of the tourist experience. This is contradicted by the results of a study by Neuts, Romão, van Leeuwen and Nijkamp (2013) which suggest that destinations that were able to provide tourists with more emotional benefits and a unique 
atmospheric image had a significant competitive advantage as the results revealed that the intangible attributes of a destination has a higher propensity of achieving destination loyalty in comparison to the physical attributes of a destination. This is also supported by a study conducted by Chen (2012) showing that the emotional benefits sought from travelling has a larger influence on destination choice as well as the frequency of travel. Hence, the relationship between the functional and emotional benefits that a destination projects through its brand essence need to match the expectations of tourists as this will undoubtedly influence their overall destination experience (Prayag, 2003). Destinations that can offer tourists with these benefits that exceed their cost of travelling to these destinations will have tourists with increased levels of satisfaction and revisit intention.

Destination loyalty: Rajesh (2013) suggests that the overall destination loyalty is influenced by the perceptions that tourists have before travelling to the destination, the perceptions that tourists have towards the destination image as well as the overall satisfaction of experience received while at the destination. The attitudes that a tourist have towards a destination are considered to be a key determinant when deciding to return to the destination. The results of a research conducted by Artuğer et al. (2013) revealed that the cognitive image a tourist has of a destination had a higher impact when establishing destination loyalty in comparison to the affective images of a destination. Further results indicated that tourists with a perceived positive image towards a destination showed a higher intention to return as well as to recommend the destination to other tourists (Artuğer et al., 2013). The results of a study conducted by Oom do Valle, Silva, Mendes and Guerreiro (2006) on tourists' satisfaction and destination loyalty intention in Arade, Portugal, revealed that tourist satisfaction had a significant influence on destination loyalty, as tourists with a higher level of satisfaction were more inclined to return and recommend the destination to others in comparison to tourists that had a lower level of satisfaction. The attitudinal dimension of destination loyalty was evident in the study of Artuğer et al. (2013) in Alanya, Turkey, as results revealed that satisfied tourists, who are not able to return to the destination, indicated that they would still recommend others to visit the destination through the spread of positive word-of-mouth. Destination loyalty is therefore largely influenced by the perceived level of satisfaction that tourists have towards their overall destination experience (Rajesh, 2013), as a positive tourist experience enhances the intent to return as well as ensures that a positive word-ofmouth is spread about the destination (Artuğer et al., 2013). It can therefore be said that Destination loyalty is influenced by the perceived satisfaction of the overall experience received, as this could influence the willingness of tourist to return to the destination as well as to recommend others to travel to the destination.

\section{Methodology}

Primary and secondary data have been used to obtain information relevant to this research.This study used a deductive approach, where theory is tested against the data collected, as the activities that tourists enjoyed in Cape Town and their relationship to how they perceive this destination using brand descriptive variables (brand essence, brand image and brand loyalty) are being investigated. Two hundred and twenty (220) tourists in Cape Town were surveyed using a structured questionnaire (respondent-completed, mostly closeended). These tourists were surveyed at the three most visited attractions in Cape Town, namely Victoria and Alfred Waterfront, Table Mountain National Park and Kirstenbosch National Botanical Gardens (The Western Cape destination marketing, investment and trade promotion agency- South Africa, 2015). Contemporary tourism is understood to be a mass phenomenon that requires much involvement from governmental, notfor-profit and for-profit organisations, as well as tourists, relying on quantified information for important aspects of decision-making (Ezeuduji, 2013; Veal, 2011). Questionnaire survey is accepted as an ideal way of getting some of this information (Veal, 2011); including tourists' perception. Questionnaires were therefore administered using non-probabilistic convenience sampling of tourists, based on key attractions' selection, availability and willingness of tourists to partake in the study. Two hundred (200) usable questionnaires were eventually returned, resulting in a $91 \%$ response rate. The study involved domestic and international tourists visiting Cape Town. A screening question was asked by the researchers in order to identify the targeted respondents. The screening question asked was "Are you living and/or working in Cape Town?" This ensured that local residents of Cape Town were not included in the study. The exclusion of local residents who may be day visitors ensures that only 'actual tourists' were targeted. 
The questionnaire battery included respondents' profile, level of visit satisfaction, activities done in Cape Town, brand essence perception, brand image perception, and brand loyalty. Questionnaire design used variables emanating from previous research: tourists' perceptions towards brand essence of Cape Town (Chen, 2012; Quintal \& Polczynski, 2010); tourists' perceptions towards the brand image of Cape Town (Nel \& Strydom, 2004; Prayag, 2010); tourists' brand loyalty towards Cape Town (Artuğer et al., 2013; Oom do Valle et al., 2006; Rajan, 2015); and level of overall experience satisfaction in Cape Town (Oom do Valle et al., 2006; Rid, Ezeuduji, \& Pröbstl-Haider, 2014). Brand essence, brand image, brand loyalty, activities, and satisfaction items were measured along a 5-point Likert scale (ordinal variables). The scale ranged from 1 (strongly disagree/ not enjoyable/ highly dissatisfied) to 5 (strongly agree/ highly enjoyable/ highly satisfied). Respondents' profile questions were sorted into categorical variables. Studies by Eriksson, Kerem, and Nilsson (2005), Hsieh and Li (2008), and Rahi (2015) used Likert type scale to measure brand essence, brand image and customer loyalty. Their validity and reliability analyses confirmed the instrument and measurement scale.

IBM's SPSS version 23 software was used for statistical analysis (IBM Corporation, 2015). The first stage of analysis used descriptive statistics to derive frequency of respondents' profile (in percentages), mean and standard deviation of brand essence, brand image and brand loyalty variables. Multivariate analyses of the data collected were done at the second stage of data analysis, to reveal the consistency of items in brand essence, brand image and brand loyalty sections. Cronbach's Alpha was calculated as reliability parameter to check the internal consistency of the variables within each section. Commonly, a cut-off point of $0.5-0.7$ is used for Cronbach Alpha values (Buehl \& Zoefel, 2005; George \& Mallery, 2003), therefore we confidently accept that a Cronbach Alpha coefficient of 0.7 and above indicates internal consistency of items, hence we can rely on those items to explain a common feature such as brand essence, brand image and brand loyalty. Finally, at the third stage of analysis, Pearson Chi-Square test was used to check for relationships between categorical variables (in this case, ordinal variables were recorded into nominal/ categorical variables), and Spearman's Correlation tests was used to check for relationships between ordinal variables (Cessford, 2003; Veal, 2011; Zondo \& Ezeuduji, 2015).

\section{Results and Discussion}

Tourists' profile: From Table 1, this study results show that female tourists dominate within the sample, and most tourists visiting Cape Town during the survey are relatively young, where $70 \%$ of them are 40 years and below, and mostly coming from abroad. More than $46 \%$ of tourists stayed 8 days or longer in Cape Town, mostly on holidays. Good news for Cape Town tourism is that repeat visits account for over $43 \%$ of the sample (depicting destination loyalty) and more than $92 \%$ of tourists indicated they were either mostly or highly satisfied with their visits. Rajesh (2013) suggests that overall destination loyalty is influenced by the perceptions that tourists have before coming to the destination, the perceptions that tourists have towards the destination image as well as the overall satisfaction of experience received while at the destination. It seems from this study therefore that Cape Town is positively perceived by its visitors.

Table 1: Profile of the respondents $(N=200)$

\begin{tabular}{lll}
\hline Variable & Category & Frequency (\%) \\
\hline Gender & Male & 42.0 \\
Age group & Female & 58.0 \\
& Less than 20 & 11.5 \\
& $21-30$ & 36.0 \\
& $31-40$ & 22.5 \\
& $41-50$ & 10.5 \\
& $51-60$ & 12.0 \\
Origin & $61-70$ & 5.5 \\
& More than 70 & 2.0 \\
Continent of origin, if not South & 35.5 \\
African & South African & 64.5 \\
\hline
\end{tabular}




\begin{tabular}{|c|c|c|}
\hline & Australia/Oceania & 12.5 \\
\hline & Europe & 46.9 \\
\hline & North America & 16.4 \\
\hline & South America & 3.9 \\
\hline \multirow[t]{2}{*}{ Repeat visit } & Yes & 43.5 \\
\hline & No & 56.5 \\
\hline Source of information about & Word of Mouth & 39.3 \\
\hline \multirow[t]{4}{*}{ Cape Town } & Internet & 33.3 \\
\hline & Media (TV, magazines, books) & 13.7 \\
\hline & Travel Agency & 12.0 \\
\hline & Other & 1.6 \\
\hline \multirow[t]{2}{*}{ Group travel } & Yes & 50.8 \\
\hline & No & 49.2 \\
\hline \multirow[t]{4}{*}{ Length of stay in Cape Town } & $1-3$ days & 16.6 \\
\hline & 4 -7 days & 37.2 \\
\hline & 8-11 days & 13.6 \\
\hline & 12 days or longer & 32.7 \\
\hline \multirow[t]{7}{*}{ Purpose of visit to Cape Town } & Holiday & 70.6 \\
\hline & Business (attending conference /seminar/ & 12.2 \\
\hline & event) & 1.7 \\
\hline & Business (importing/ exporting goods) & 12.8 \\
\hline & Visiting friends and relatives & 1.1 \\
\hline & Medical care & 1.7 \\
\hline & Academic exchange & \\
\hline \multirow[t]{3}{*}{ Level of experience satisfaction } & Highly or mostly satisfied & 92.4 \\
\hline & Moderately satisfied & 6.1 \\
\hline & Mostly or highly dissatisfied & 1.5 \\
\hline
\end{tabular}

Tourists' activity versus level of experience satisfaction: Tourists were asked to indicate how they enjoyed the main activities in Cape Town. Table 2 shows that in as much as tourists in Cape Town indicated that they enjoyed much of the activities they engaged in; there are no statistical relationships between activity enjoyment and level of experience satisfaction for beach, historical and cultural activities. Nature and outdoor, food and wine, and beach activities seem to be quite popular among tourists in Cape Town. However, only nature and outdoor, and food and wine have strong positive correlation with the tourists level of general experience satisfaction. Shopping activity also was found to have some relationship with general experience satisfaction. It can therefore be interpreted that nature and outdoor, food and wine, and shopping enjoyment have some impact in determining the general experience satisfaction of tourists in Cape Town. As Pawitra \& Tan (2003) and Vengesayi (2003) posited, the quality of the physical infrastructure and facilities of a destination such as accommodation and transportation network systems form the foundation upon which tourism services are produced in a destination, while the variety of attraction and activities of a destination serves as a pull factor during the decision making of potential tourists. Puh (2014), also stated that the overall perceptions that a tourist has of a destination is a multidimensional construct, as it is influenced by a number of external information sources as well as by the direct destination experience. 
Table 2: Activities in Cape Town versus level of general experience satisfaction $(\mathrm{N}=\mathbf{2 0 0})$

\begin{tabular}{|c|c|c|c|c|}
\hline $\begin{array}{l}\text { Activities in Cape } \\
\text { Town }\end{array}$ & $\begin{array}{l}\text { Not enjoyable } \\
\text { or mostly } \\
\text { unenjoyably } \\
(\%)\end{array}$ & $\begin{array}{l}\text { Moderately } \\
\text { enjoyable (\%) }\end{array}$ & $\begin{array}{l}\text { Mostly } \\
\text { enjoyable or } \\
\text { highly } \\
\text { enjoyable (\%) }\end{array}$ & $\begin{array}{l}\text { Compared with level of } \\
\text { general } \\
\text { satisfaction }\end{array}$ \\
\hline $\begin{array}{l}\text { Nature } \\
\text { outdoors }\end{array}$ & 4.1 & 8.2 & 87.7 & $\begin{array}{l}\text { *** The more the tourists } \\
\text { enjoyed 'nature and } \\
\text { outdoor' activities, the } \\
\text { higher the level of general } \\
\text { experience satisfaction. }\end{array}$ \\
\hline Food and wine & 5.4 & 14.5 & 80.1 & $\begin{array}{l}\text { ** The more the tourists } \\
\text { enjoyed 'food and wine', the } \\
\text { higher the level of general } \\
\text { experience satisfaction. }\end{array}$ \\
\hline Beaches & 5.2 & 15.1 & 79.7 & NS \\
\hline History and culture & 4.5 & 20.5 & 75.0 & NS \\
\hline Shopping & 8.3 & 26.3 & 65.4 & $\begin{array}{l}\text { *The more the tourists } \\
\text { enjoyed 'shopping', the } \\
\text { higher the level of general } \\
\text { experience satisfaction. }\end{array}$ \\
\hline
\end{tabular}

Notes: Spearman's Correlation test significance. ${ }^{*}, p<0.05$; $^{* *}, p<0.01 ;{ }^{* * *}, p<0.000$.

NS, no significant results.

Brand perception: The internal consistencies of variables used in measuring brand statements (essence, image and loyalty) were tested using Cronbach's Alpha reliability test. Results show a Cronbach's Alpha values of more than 0.7 (Buehl \& Zoefel, 2005; George \& Mallery, 2003), indicating internal consistency of items within the brand essence, brand image and brand loyalty dimensions. Hence we can rely on those items to explain a common feature such as brand essence, brand image and brand loyalty.

Table 3: Brand statements' reliability tests $(N=200)$

\begin{tabular}{|c|c|c|c|}
\hline Brand essence & Mean & $\begin{array}{l}\text { Standard } \\
\text { deviation }\end{array}$ & $\mathbf{N}$ \\
\hline $\begin{array}{l}\text { Cape Town provides tourists with authentic visitor } \\
\text { experience }\end{array}$ & 4.14 & .801 & 192 \\
\hline My visit to Cape Town has been valuable to me & 4.28 & .795 & 192 \\
\hline My visit to Cape Town will be memorable & 4.50 & .752 & 192 \\
\hline $\begin{array}{l}\text { I have gained new knowledge and experience during my } \\
\text { visit to cape Town }\end{array}$ & 4.26 & .833 & 192 \\
\hline $\begin{array}{l}\text { The local people in Cape Town are friendly and } \\
\text { hospitable }\end{array}$ & 3.94 & .944 & 192 \\
\hline \multicolumn{4}{|l|}{ Reliability Statistics, Cronbach's Alpha $=.812, N$ of Items $=5$} \\
\hline \multicolumn{4}{|c|}{ Valid cases $=192(96 \%)$, Excluded cases $=8(4 \%)$, Total $=200 ;$ Overall mean $=4.22$} \\
\hline \multicolumn{4}{|c|}{ Scale: 1(strongly disagree); 2(disagree); 3(neutral); 4(agree); 5(strongly agree) } \\
\hline Brand image & Mean & $\begin{array}{l}\text { Standard } \\
\text { deviation }\end{array}$ & $\mathrm{N}$ \\
\hline I feel safe while travelling around Cape Town & 3.61 & 1.024 & 184 \\
\hline Cape town has unique and diverse attractions & 4.38 & .766 & 184 \\
\hline $\begin{array}{l}\text { The price of facilities and services (food \& beverages, } \\
\text { accommodation, entry fees, souvenirs) in Cape Town are } \\
\text { reasonable }\end{array}$ & 4.02 & 1.002 & 184 \\
\hline $\begin{array}{l}\text { The overall service received at facilities (restaurants, } \\
\text { accommodation, attractions) is of high quality }\end{array}$ & 4.07 & .744 & 184 \\
\hline Cape Town provides tourists with good value for money & 4.11 & .870 & 184 \\
\hline \multicolumn{4}{|l|}{ Reliability Statistics, Cronbach's Alpha $=.765, \mathrm{~N}$ of Items $=5$} \\
\hline \multicolumn{4}{|c|}{ Valid cases $=184(92 \%)$, Excluded cases $=16(8 \%)$, Total $=200 ;$ Overall mean $=4.04$} \\
\hline
\end{tabular}




\begin{tabular}{|c|c|c|}
\hline Brand loyalty & Mean & $\begin{array}{l}\text { Standard } \\
\text { deviation }\end{array}$ \\
\hline Cape Town is one of the best places I have ever been to & 3.94 & .927 \\
\hline $\begin{array}{l}\text { Cape Town would be my preferred choice when choosing } \\
\text { a destination to visit }\end{array}$ & 3.88 & .879 \\
\hline I would consider visiting Cape Town in the future & 4.26 & .878 \\
\hline I would recommend Cape Town to my family and friends & 4.43 & .693 \\
\hline $\begin{array}{l}\text { I would say positive things about Cape Town to my } \\
\text { family and friends } \\
\text { Reliability Statistics, Cronbach's Alpha }=.861, N \text { of Items }=5 \\
\text { Valid cases }=198(99 \%), \text { Excluded cases }=2(1 \%), \text { Total }=200 ; \\
\text { Scale: } 1 \text { (strongly disagree); } 2 \text { (disagree); } 3 \text { (neutral); } 4 \text { (agree) }\end{array}$ & 4.39 & .751 \\
\hline
\end{tabular}

Results show that tourists generally perceive Cape Town well, agreeing or strongly agreeing to the items in Table 3. Amongst all the items used in measuring brand perceptions, "I feel safe while travelling around Cape Town" had the lowest mean score. This means that tourists in Cape Town do still have some reservations concerning safety issues, in terms of crime. Ezeuduji (2003) therefore advised that strong police presence and proper policing in South Africa (such as, instilling the values of zero-tolerance for crime and responsiveness within the South African Police service) will be effective in dealing with crime in South Africa, and reducing the negative perception of tourists towards South African destinations. Local community collaboration with the police force can also help to curb crimes in South Africa. As Rajesh (2013) and Lopes (2011) posited, brand image is a multidimensional construct as it is influenced by a number of factors from the tourist's perspective, such as cognitive images (destination attributes), and affective images (emotional evaluation of destination attributes).

Brand statements versus activities in Cape Town: Tourists were asked to indicate how they enjoyed or not enjoyed main tourists' activities in Cape Town, and also indicate their level of agreement with brand perception statements (brand essence, brand image and brand loyalty) about Cape Town in Table 4. This study found mostly that the more tourists enjoyed these activities, the more they agree to most of the brand statements. However, the questionnaire brand essence item - "the local people in Cape Town are friendly and hospitable" did correlate positively with "nature and outdoor" activities, only. Tourists' most likelihood to encounter many locals doing 'nature and outdoor' activities may have influenced them to perceive Cape Town local population as being friendly and hospitable. A brand essence questionnaire item ("my visit to Cape Town will be memorable"), and a brand image item ("Cape Town has unique and diverse attractions") stand out from the rest items (see Table 4), as all the tourists' activities correlated positively with these two brand statements. We can therefore deduce that the brand position statement for Cape Town should strongly revolve around unique and diverse attractions, and memorable experience. Cape Town's brand essence (consisting of the functional and emotional benefits of visiting this destination) can therefore be linked to its competitive advantages of unique and diverse attractions, and providing a memorable experience to its tourists (Ezeuduji, 2015). These unique and diverse attractions that can impact on visitor experience include the popular Victoria and Alfred Waterfront, Table Mountain, Cape Point, Cape wine routes, Kirstenbosch, Robben Island, etc.

Table 4: Brand statements versus activities in Cape Town $(\mathrm{N}=\mathbf{2 0 0})$

\begin{tabular}{llllll}
\hline Brand essence & $\begin{array}{l}\text { Nature } \\
\text { outdoor }\end{array}$ & $\begin{array}{l}\text { \& } \\
\text { Food } \\
\text { wine }\end{array}$ & Beaches & $\begin{array}{l}\text { History } \\
\text { c } \\
\text { culture }\end{array}$ & Shopping \\
\hline $\begin{array}{l}\text { Cape Town provides tourists with authentic } \\
\text { visitor experience }\end{array}$ & NS & $* *$ & NS & $*$ & $* * *$ \\
$\begin{array}{l}\text { My visit to Cape Town has been valuable to } \\
\text { me }\end{array}$ & $* * *$ & $*$ & NS & $* *$ & $* *$ \\
$\begin{array}{l}\text { My visit to Cape Town will be memorable } \\
\begin{array}{l}\text { I have gained new knowledge and } \\
\text { experience during my visit to cape Town }\end{array}\end{array}$ & $* *$ & & & & \\
The local people in Cape Town are friendly & $* * *$ & NS & $* * *$ & $* *$ & $* *$ \\
\hline
\end{tabular}




\begin{tabular}{|c|c|c|c|c|c|}
\hline and hospitable & & & & & \\
\hline Brand image & & & & & \\
\hline $\begin{array}{l}\text { I feel safe while travelling around Cape } \\
\text { Town }\end{array}$ & $*$ & $*$ & $*$ & NS & $*$ \\
\hline $\begin{array}{l}\text { Cape town has unique and diverse } \\
\text { attractions }\end{array}$ & $* *$ & $* * *$ & $* * *$ & $* *$ & $* * *$ \\
\hline $\begin{array}{l}\text { The price of facilities and services (food \& } \\
\text { beverages, accommodation, entry fees, } \\
\text { souvenirs) in Cape Town are reasonable }\end{array}$ & NS & $* *$ & NS & NS & * \\
\hline $\begin{array}{l}\text { The overall service received at facilities } \\
\text { (restaurants, accommodation, attractions) } \\
\text { is of high quality }\end{array}$ & $* * *$ & $* *$ & NS & NS & * \\
\hline $\begin{array}{l}\text { Cape Town provides tourists with good } \\
\text { value for money }\end{array}$ & $*$ & $* * *$ & $* *$ & NS & $*$ \\
\hline Brand loyalty & & & & & \\
\hline $\begin{array}{l}\text { Cape Town is one of the best places I have } \\
\text { ever been to }\end{array}$ & * & NS & ** & * & $* *$ \\
\hline $\begin{array}{l}\text { Cape Town would be my preferred choice } \\
\text { when choosing a destination to visit }\end{array}$ & NS & NS & $* *$ & $*$ & * \\
\hline $\begin{array}{l}\text { I would consider visiting Cape Town in the } \\
\text { future }\end{array}$ & NS & $*$ & $* * *$ & $* *$ & $* *$ \\
\hline $\begin{array}{l}\text { I would recommend Cape Town to my } \\
\text { family and friends }\end{array}$ & NS & $*$ & $* *$ & $* *$ & * \\
\hline $\begin{array}{l}\text { I would say positive things about Cape } \\
\text { Town to my family and friends }\end{array}$ & $* * *$ & $*$ & NS & NS & NS \\
\hline
\end{tabular}

Notes: Spearman's Correlation test significance. ${ }^{*}, p<0.05$; $^{* *}, p<0.01$; ${ }^{* *}, p<0.000$. NS, no significant results.

Interpretation of results: Where result is significant, the more tourists enjoyed an activity, the more they agree to the corresponding brand statements. This Cape Town's tourism position statement communicates core functional benefits (unique and diverse attractions) and emotional benefit (memorable experience). Cape Town tourism may therefore integrate this brand position statement into its integrated marketing communications, in its continual endeavour to justify and preserve her assets of reputation (Ezeuduji, 2015).

\section{Conclusion}

This study finds that although tourists found most activities in Cape Town enjoyable; nature and outdoor, food and wine, and shopping enjoyment have more impact in determining the general experience satisfaction of tourists, than beach, history and cultural activities. Tourists in Cape Town do have some reservations concerning safety issues, in terms of crime. Strong police presence and proper policing in Cape Town will be effective in dealing with crime, and reducing the negative perception of tourists towards this destination. Local community collaboration with the police force can also help to curb crimes in Cape Town. Nevertheless, tourists generally perceive Cape Town quite positively. This research also deduced that the brand position statement for Cape Town should strongly revolve around unique and diverse tourists' attractions in Cape Town, and the memorable experience with which tourists go home from Cape Town. Thus suggesting that Cape Town tourism's brand position statement could read -"To tourists seeking highly memorable experience, Cape Town offers unique and diverse attractions". This brand position statement, communicating both the functional and emotional benefits of visiting this destination, should be linked to Cape Town tourism's integrated marketing communications, such as in advertising and public relations. 


\section{References}

Airport Company of South Africa. (2015). Cape Town arrival passengers- August 2015. Retrieved 11 September 2015, from http://www.acsa.co.za/uploads/PassengerStatistics /CPT_Arrival_Passangers_August2015.pdf.

Albayrak, T., Caber, M. \& Aksoy, Ș. (2010). Relationships of the tangible and intangible elements of tourism products with overall customer satisfaction. International Journal of Trade, Economics and Finance, $1(2), 140-143$.

Artuğer, S., Çetinsöz, B. C. \& Kiliç, I. (2013). The effect of destination image on destination loyalty: An application in Alanya. European Journal of Business and Management, 5(13), 124-136.

Awuah, G. B. \& Reinert, V. (2011). Potential tourists' image of a tourist destination: The case of Brazil. In SvenÅke, H (Ed.). Research on Technology, Innovation and Marketing Management 2009-2011: Introducing the Research Area of Innovation Science. Halmstad: Högskolani Halmstad: 135-148. Retrieved 09 December 2015, from http://www.divaportal.org/smash/get/diva2:452288/FULLTEXT01.pdf

Beerli, A. \& Martin, J. D. (2004). Tourists' characteristics and the perceived image of tourist destinations: A quantitative analysis- a case study of Lanzarote, Spain. Tourism Management, 25, 623-636.

Bertan, S. \& Altintaş, V. (2013). Visitors' perception of a tourism destination: The case of Pamukkale. Tourismos: An International Multidisciplinary Journal of Tourism, 8(1), 115-132.

Buehl, A. \& Zoefel, P. (2005). SPSS 12. Einführung in die modern Datenanalyseunter Windows. München: Addison-Wesley.

Cessford, G. (2003). Perception and reality of conflict: walkers and mountain bikes on the Queen Charlotte Track in New Zealand. Journal for Nature Conservation, 11(4), 310-316.

Chen, C. C. (2012). Why people travel? Examining perceived benefits of tourism. Unpublished PhD dissertation, Texas A\&M University, Texas. Retrieved 09 December 2015, from http://search.proquest.com/docview/1319255149

City of Cape Town. (2013). Tourism development framework: 2013 to 2017 for the City of Cape Town. Cape Town: City of Cape Town.

Crouch, G. I. (2011). Destination competitiveness: an analysis of determinant attributes. Journal of Travel Research, 50(1), 27-45.

deChernatony, L. \& Harris, F. (2010). The strategic process of building and sustaining brands. Milton Keynes: The Open University Business School.

deChernatony, L. \& McDonald, M. (1998). Creating powerful brands in consumer, service and industrial markets (2nd Ed.). Oxford: Butterworth-Heinemann.

Dick, B. K. (1994). Customer loyalty: Toward an integrated conceptual framework. Journal of the Academy of Marketing Science, 22, 99-113.

Dimmock, K. (2012). The tourism and leisure experience: consumer and managerial perspectives. Annals of Leisure Research, 15(1), 110-111.

Dwyer, L. \& Kim, C. (2003). Destination competitiveness: determinants and indicators. Current Issues in Tourism, 6(5), 369-414.

Edvardsson, B., Johnson, M. D., Gustafsson, A. \& Strandvik, T. (2000). The effects of satisfaction and loyalty on profits and growth: products versus services. Total Quality Management, 11(7), 917-927.

Eriksson, K., Kerem, K. \& Nilsson, D. (2005). Customer acceptance of internet banking in Estonia. International Journal of Bank Marketing, 23, 200-216.

Ezeuduji, I. 0. (2013). Nigerian tourists to South Africa: Challenges, expectations and demands. Acta Commercii, 13(1), 1- 9.

Ezeuduji, I. O. (2015). Brand Positioning for Sub-Saharan Africa's Rural Tourism Development. Journal of Economics and Behavioral Studies, 7(6), 34-41.

Ezeuduji, I. O., Lete, P. M., Correia, M. \& Taylor, A. (2014). Competitive advantage for brand positioning: The case of Sun City in South Africa. Tourism Review International, 17, 299 - 306.

George, D. \& Mallery, P. (2003). SPSS for Windows step by step: A simple guide and reference, 11.0 update (4th Ed.). Boston: Allyn \& Bacon.

Gao, B. O. \& Zhang, H. Q. (2009). Dream Destination: A concept of perception of leisure travellers. International CHRIE Conference-Refereed Track (p.26), Amherst, 6 August 2009. Amherst: University of Massachusetts. 
Gursoy, D., Chen, J. S. \& Chi, C. G. (2014). Theoretical examination of destination loyalty formation. International Journal of Contemporary Hospitality Management, 26(5), 809-827.

Gâslason, S. (2013). Sustainability Certification of Nordic Tourist Destinations: Report from an Expert Workshop in Stockholm 11th September 2012. Copenhagen: Nordic Council of Ministers.

George, R. (2011). Marketing tourism in South Africa (4th Ed.) Cape Town: Oxford University Press.

Hallowell, R. (1996).The relationships of customer satisfaction, customer loyalty, and profitability: an empirical study. International Journal of Service Industry Management, 7, 27-42.

Hosany, S., Ekinci, Y. \& Uysal, M. (2007). Destination image and destination personality. International Journal of Culture, Tourism and Hospitality Research, 1(1), 62 - 81.

Hsieh, A. T. \& Li, C. K. (2008). The moderating effect of brand image on public relations perception and customer loyalty. Marketing Intelligence and Planning, 26, 26-42.

IBM Corporation. (2015). IBM SPSS Statistics for Windows, Version 23.0. Armonk, NY: IBM Corp.

Ibrahim, E. E. \& Gill, J. (2005). A positioning strategy for a tourist destination, based on analysis of customers' perceptions and satisfactions. Marketing Intelligence \& Planning, 23(2), 172-188.

Jraisat, L. E., Akroush, M. N., Alfaouri, R. J., Qatu, L. T. \& Kurdieh, D. J. (2015). Perceived brand salience and destination brand loyalty from international tourists' perspectives: The case of Dead Sea destination, Jordan. International Journal of Culture, Tourism and Hospitality Research, 9(3), 292-315.

Kapferer, J. N. (1997). Strategic brand management (2nd Ed.). London: Kogan Page.

Keller, K. (2003). Strategic brand management: Building, measuring, and managing brand equity, Upper Saddle River, NJ: Pearson Education International.

Kiliç, B. \& Sop, S. A. (2012). Destination personality, self-congruity and loyalty. Journal of Hospitality Management and Tourism, 3(5), 95-105.

Light, L., Kiddon, J., Till, B. D., Heckler, D., Matthews, R. D., Hall, R. \& Wacker, W. (2012). Branding strategies for success. Upper Saddle River, NJ: FT Press.

Lopes, S. D. F. (2011). Destination image: Origins, developments and implications. Revista de Turismo y Patrimonio Cultural, 9(2), 305-315.

Molina, A., Gómez, M. \& Martín-Consuegra, D. (2010). Tourism marketing information and destination image management. African Journal of Business Management, 4(5), 722-728.

Murphy P., Pritchard, M. \& Smith, B. (2000). The destination product and its impact on traveller perceptions. Tourism Management, 21(1), 43-52.

Nel, R. G. \& Strydom, A. J. (2004). The role of image / perception in urban tourism development: A case study of Bloemfontein. Interim: Interdisciplinary Journal, 3(2), 166-185.

Neuts, B., Romão, J., van Leeuwen, E. \& Nijkamp, P. (2013). Describing the relationships between tourist satisfaction and destination loyalty in a segmented and digitalized market. Tourism Economics, 19(5), 987-1004.

New York Times. (2014). 52 places to go in 2014. Retrieved 14 March 2015, from http://www.nytimes.com/interactive/2014/01/10/travel/2014-places-to-go.html

Okumuş, A. \&Yaşin, B. (2008). Examining the image of Italy, France and Morocco as a tourist destination. The 4th World Conference for Graduate Research in Tourism, Hospitality and Leisure: p. 12-24, Antalya, Turkey, 22-27 April 2008.

Oom do Valle, P., Silva, J. A., Mendes, J. \& Guerreiro, M. (2006). Tourist satisfaction and Destination loyalty intention: A structural and categorical analysis. International Journal of Business Science and Applied Management, 1(1), 25-44.

O'Sullivan, T. (2010). Marketing communications. Milton Keynes: The Open University Business School.

Pawitra, T. A. \& Tan, K. C. (2003). Tourist satisfaction in Singapore - a perspective from Indonesian tourists. Managing Service Quality: An International Journal, 13(5), 399 - 411.

Perović, D., Stanovčić, T., Moric, I. \& Pekovic, S. (2012). What socio-demographic characteristics do influence the level of tourist's satisfaction in Montenegro? Empirical analysis. Journal of Tourism, 14, 5-10.

Prayag. G. (2003). An investigation into international tourists' perceptions of Cape Town as a holiday destination: one destination-an unforgettable experience. Unpublished Masters of Business Science thesis. Cape Town: University of Cape Town.

Prayag, G. (2007). Positioning the city product as an international tourist destination: Evidence from South Africa. Turizam: znanstveno-stručničasopis, 55(2), 139-155.

Prayag, G. (2010). Brand image assessment: International visitors' perceptions of Cape Town. Marketing intelligence \& planning, 28(4), 462- 485. 
Puh, B. (2014). Destination Image and Tourism Satisfaction: The Case of a Mediterranean Destination. Mediterranean Journal of Social Sciences, 5(13), 538-544.

Qu, H., Kim, L. H. \&Im, H. H. (2011). A model of destination branding: Integrating the concepts of the branding and destination image. Tourism Management, 32, 465-476.

Quintal, V. A. \& Polczynski, A. (2010). Factors influencing tourists' revisit intentions. Asia Pacific Journal of Marketing and Logistics, 22(4), 554 - 578.

Rahi, S. (2015). Moderating role of brand image with relation to Internet banking and customer loyalty: A case of branchless banking. Journal of Internet Banking \& Commerce, 20(3), 1-6.

Rajan, V. (2015). Factors affecting tourist destination loyalty: A case study of Munnar, India as a tourism destination. International Conference on Business, Economics and Management, p. 18-21, Phuket, Thailand, 9-10 April 2015.

Rajesh, R. (2013). Impact of tourist perceptions, destination image and tourist satisfaction on destination loyalty: A conceptual model. Revista de Turismo y Patrimonio Cultural, 11(3), 67-78.

Rid, W., Ezeuduji, I. O. \& Pröbstl-Haider, U. (2014). Segmentation by motivation for rural tourism activities in the Gambia. Tourism Management, 40, 102-116.

Rossiter, J. \& Percy, L. (1996). Advertising communications and promotion management. New York, NY: McGraw Hill.

South African Tourism. (2015). South African Tourism Strategic Plan 2015 - 2020. Pretoria: South African Tourism.

Tasci, A. D. A. \& Gartner, W. C. (2007). Destination image and its functional relationships. Journal of Travel Research, 45(4), 413-425.

The Western Cape Destination Marketing, Investment and Trade Promotion Agency of South Africa. (2013). Tourism strategy 2014/2015. Cape Town: WESGRO

The Western Cape Destination Marketing, Investment and Trade Promotion Agency of South Africa. (2015). Visitor number to Western Cape on the rise; bold tourists go off the beaten track. Retrieved 12 March 2015, from http://wesgro.co.za/corporate/press-releases/visitor-numbers-to-western-cape-on-therise-bold-tourists-go-off-the-beaten-track

Veal, A. J. (2011). Research methods for leisure and tourism: A practical guide (4th Ed.). Harlow, UK: Financial Times Prentice Hall.

Vengesayi, S. (2003). Conceptual model of tourism destination competitiveness and attractiveness, Australia and New Zealand Marketing Academy Conference Proceedings, p. 637-647, Adelaide, Australia, 1-3 December 2003.

Wijethunga, W. \& Warnakulasooriya, B. (2014). Destination image perception of international tourists: the case of Sri Lanka as a tourist destination. 11th International Conference on Business Management 2014, Colombo, 11-12 December 2014.

Zondo, P. K. \& Ezeuduji, I. O. (2015). Comparing local and international tourists' perceptions of service experience dimensions of an attraction and a destination: the case of South Africa. African Journal of Hospitality, Tourism and Leisure, 4(2), 1-15. 